\title{
Determination of rational modes of pumpkin seeds drying
}

\author{
Vadym Pazyuk ${ }^{1}$, Zhanna Petrova ${ }^{1}$, Oleksandr Chepeliuk ${ }^{2}$ \\ 1 - Institute of Engineering Thermophysics of NAS of Ukraine, Kyiv \\ 2 - National University of food Technologies, Kyiv, Ukraine
}

Keywords:

Pumpkin

Seed

Drying

Germination

\section{Article history:}

Received

11.12.2017

Received in

revised form

14.02 .2018

Accepted

29.03.2018

Corresponding

author:

Oleksandr

Chepeliuk

E-mail:

almeat@ukr.net

DOI:

$10.24263 / 2304-$

974X-2018-7-1-12

\section{Abstract}

Introduction. Pumpkin seeds are an easily accessible source of protein and other useful substances. A purpose is to determine a rational mode of its drying, which ensures high germinability of the seeds.

Materials and methods. The physical and mechanical properties of pumpkin seeds «Stofuntovyi» of Ukrainian selection with a humidity of $0,6,16,46 \%$ have been investigated. The drying process kinetics have been investigated on a test bench of convective drying at the following conditions: the drying agent temperature in the drying chamber $\mathrm{t}=40-80^{\circ} \mathrm{C}$, velocity $\mathrm{V}=1,5 \mathrm{~m} / \mathrm{s}$, the moisture content of dry air $\mathrm{d}=10 \mathrm{~g} / \mathrm{kg}$ d.a. The biochemical properties of dried pumpkin seeds were determined by the amount of seeds capable of forming normally developed sprouts under optimal conditions on the $5^{\text {th }}, 7^{\text {th }}$ and $10^{\text {th }}$ days of germination.

Results and discussion. The studies of the properties of pumpkin seeds variety have revealed that when the initial moisture content in the material changes from 0 to $46 \%$, there is an increase in the seeds' geometric sizes: the length increases by $38 \%$, width - by $10 \%$ and thickness - by $8 \%$. Other parameters change too.

Investigation of the pumpkin seeds drying process has shown that when the temperature of the drying agent increases, the drying intensity increases also. In particular, the drying time reduces 8 times when the drying agent temperature is raised from 40 to $80^{\circ} \mathrm{C}$.

The drying rate curves corresponding to the falling drying rate period with preheating indicate that the highest drying rate at the maximum critical point at a drying agent temperature of $80{ }^{\circ} \mathrm{C}$ is $2.32 \% / \mathrm{min}$, and the lowest at $40{ }^{\circ} \mathrm{C}$ is $0.33 \% / \mathrm{min}$.

The heating of the pumpkin seeds takes 3 to 5 minutes depending on the mode, then the temperature of the material does not change significantly and deviates from the temperature of the drying agent by $0.1-0.5^{\circ} \mathrm{C}$.

The generalized curve of kinetics of pumpkin seeds drying makes it possible to describe the general process at different drying modes.

Conclusions. The drying agent temperature substantially affects the pumpkin seeds germinability. The most rational mode of drying is at a temperature of $40{ }^{\circ} \mathrm{C}$ and an air speed of $1.5 \mathrm{~m} / \mathrm{s}$. 


\section{Introduction}

The consumer properties of pumpkin seeds are widely known in the world market. It is an easily accessible source of protein and other useful substances. A demand for seeds grows under the influence of the trend on healthy eating, the propagation of vegetarianism and the dietetics development.

For the pumpkin seeds processing and storage, it is important to know its geometric parameters and physical and mechanical properties, in particular: length, width, height, weight of 1000 seeds, density and bulk density, which affect the equipment productivity and product losses (Joshi, D.C., and Mukherejee R.K., 1993) [1].

Many researchers studied the technical properties of different crops: melon (Davies R.M, 2010) [2], watermelon (Koocheki, A. et al., 2007) [3], soybeans (Manuwa, S.I and G.G Afuye, 2004) [4], cocoa beans (Bart-plange and Baryeh, 2003) [5], wheat (Tabatabaeefa, 2003) [6].

Usually, the drying of capillary-porous materials is carried out in two or three stages. Drying of pumpkin seeds takes place at the period of the falling drying rate, and, at the end of the period, the drying rate is significantly reduced.

Several scientists had researched the drying process of pumpkin seeds. So in Sacilik, K. (2007) [7], the pumpkin seeds drying by sunlight at an ambient temperature of 10 to 50 ${ }^{\circ} \mathrm{C}$ is considered. The drying time was 24 hours and the drying occurred during the incident drying rate.

The change in the distribution of equilibrium humidity in pumpkin seeds during drying by sunlight is shown for drying time of $0.5,1,2,5,10,15,20,25,30,34$ hours (E.Akyol et al., 2015) [8].

Guiné et al. (2011) [9] dried the pumpkin seeds in a drying chamber and showed that the drying air temperature significantly affects the drying time: at an air temperature of 30 ${ }^{\circ} \mathrm{C}$, drying lasts for 8 hours, with an increase in temperature to $70{ }^{\circ} \mathrm{C}$ it takes only 2 hours. Hashim et al. (2014) [10] carried out an experimental study of the drying of pumpkin seeds using a convection dryer with hot air (drying of samples of pumpkin seeds had taken place at a temperature of $50^{\circ} \mathrm{C}, 60^{\circ} \mathrm{C}$ and $70{ }^{\circ} \mathrm{C}$ ).

The problems of determining the rational modes of drying of pumpkin seeds and their effect on germinability in these works were not considered. Therefore the purpose of this work is to determine the most appropriate drying regimes to ensure a high germinability of the material.

Analyzing the duration of the drying process of seeds, the researchers proceeded from the fact that the layer can be represented as the sum of thin layers. The dependence of moisture evaporation of which approximates the equation of the drying rate of the elementary layer $[11,12,13]$.

One of these methods, developed by Hukil [11] and improved by Kofaid [12], makes it possible to determine the change in seeds moisture from drying time at any given time.

The basis of another method for calculating the drying time in a layer of seeds is the equation of the drying rate of the elementary layer [13]. This method is called "stepped". In the mass of the seeds, a thin (elementary) layer may be chosen, so that the air flow, related to the mass of the material, was high enough. Then any mass of seeds can be considered as the sum of elementary layers, passing through which, the air has been saturated of evaporated moisture. The degree of saturation depends on the parameters of the drying agent and the number of passed elementary layers. 


\section{Materials and methods}

The biochemical properties of pumpkin seeds «Stofuntovyi» of Ukrainian selection, which were dried on a test bench of convective drying, were determined by a method that allows determining the amount of seeds capable of forming normally developed sprouts under optimal germinability conditions.

\section{Method for determining biochemical characteristics of pumpkin seeds}

The biochemical properties of seeds include: viability, germinability, germination energy.

The viability is a measure of the percentage of seeds with an alive embryo in the total amount of seeds. The viability test makes it possible to exclude processing of low-quality seeds in a timely manner.

Germinability is the ability of seeds to form normally developed sprouts under optimal conditions. It is determined by the percentage of germinated seeds in the total amount of seeds. Small pumpkin seeds are germinated on moistened filter paper. The quantity of germinating seeds is less than the quantity of viable seeds.

The germination energy characterizes how unanimously the seeds germinate on $5^{\text {th }}$ and $7^{\text {th }}$ days.

\section{Preparation and analysis of pumpkin seeds germinability}

1. Thermostats once in 10 days, and the dishes before each test were washed with hot water with detergents and were disinfected with $1 \%$ solution of potassium permanganate or alcohol. A pallet with water was placed in the working chamber of the thermostat. Petri dishes were sterilized in a drying chamber at a temperature of $(130+2)^{\circ} \mathrm{C}$ for an hour.

2. The germinability of pumpkin seeds was analyzed. For that purpose, 100 seeds were counted at random by 10 pcs. The seeds were evenly distributed on moistened filter paper. The test was carried out on a single layer of moistened paper placed in Petri dishes covered with glass plates.

3. The germinability of pumpkin seeds under different drying conditions was analyzed at a temperature of $20^{\circ} \mathrm{C}$ for 7 days. The germination energy, seed germination and abnormal sprouts (damaged, weak, rotten, undeveloped and dead) were determined on $5^{\text {th }}, 7^{\text {th }}$ and $10^{\text {th }}$ days, respectively.

Method of conducting an experiment when drying pumpkin seeds on a test bench of convective drying

The movement speed of the drying agent has been chosen based on the drying efficiency in existing modern dryers $(\mathrm{V}=1.5 \mathrm{~m} / \mathrm{s})$.

1. Before starting the tests, the initial humidity of pumpkin seeds was determined.

When determining the dry matter or moisture in seeds, a band-and-hook hinge weighing 3$5 \mathrm{~g}$ with an uncertainty of not more than $0,01 \mathrm{~g}$ was taken from the investigated selected material put in a dry weighing bottle and installed with an open lid in a drying oven at a temperature of $100-105^{\circ} \mathrm{C}$ for 3 hours. 
After 3 hours of drying, the weighing bottles with seeds were removed from the drying oven and were placed in a desiccator for cooling for 15-30 minutes. It is assumed that a constant mass is achieved if the difference between two successive weighings does not exceed $0.004 \mathrm{~g}$. The cooled weighing bottles with pumpkin seeds were weighed with a closed lid on analytical scales. To calculate the weight of bottle with a band-and-hook hinge has become a rule

The initial moisture content of the pumpkin seeds relative to the dry mass of the substance was determined by the formula:

$$
W=\frac{m_{2}-m_{3}}{m_{3}-m_{1}} \cdot 100 \%,
$$

where $m_{l}$ - the mass of an empty weighing bottle (with a lid), g;

$m_{2}$ - the mass of the weighing bottle with a band-and-hook hinge of the seeds before drying, g;

$m_{3}$ - the mass of the weighing bottle with a band-and-hook hinge of the seeds after drying, $g$.

As a result of tests, the arithmetic mean of two parallel determinations was taken. Calculations were made with an uncertainty no more than $0.001 \%$. Differences between two parallel definitions did not exceed $0.25 \%$.

To determine the current, variable moisture content of the sample, an absolutely dry mass of seeds was determined:

$$
G_{a . c .}=G_{\kappa}-\frac{G_{\kappa} \cdot W_{\kappa}}{100},
$$

where $G_{a . c .}-$ absolutely dry mass of seeds, $g$;

$G_{k^{-}}$mass of seed sample after drying on the test bench, $\mathrm{g}$;

$W_{k}-$ residual moisture content of pumpkin seeds, $\%$.

2. A convection drying test bench for pumpkin seeds drying works together with automated system for collecting and processing information.

After setting a drying mode on a drying test bench [15] a mesh saucer by dimension $100 \times 50 \times 4 \mathrm{~mm}$ with seeds was installed on the scales bar in the drying chamber 1 (Figure 1 ) and a thermocouples were inserted in the middle of the sample to measure the material temperature.

At the same time, a computer program for collecting and processing information was turned on. 


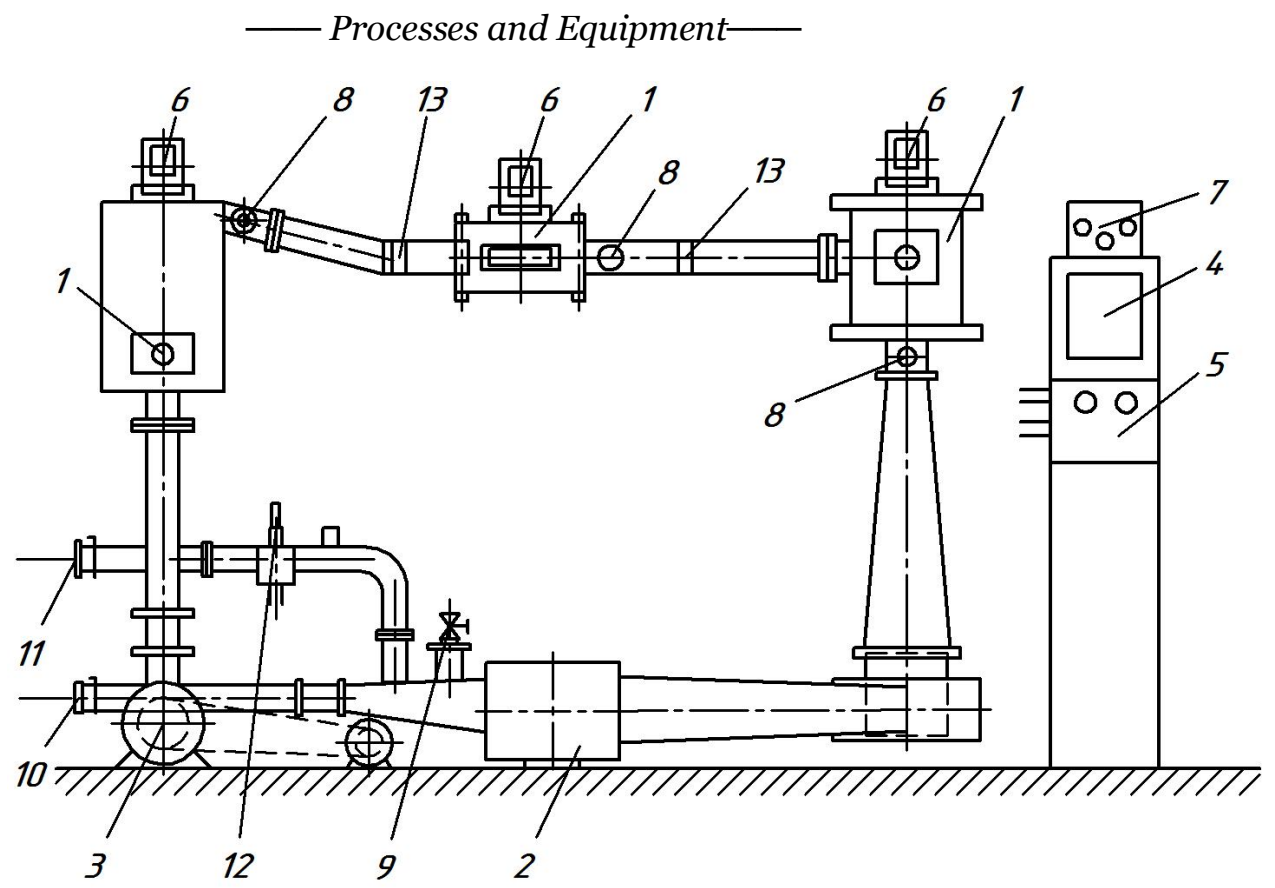

Figure 1. Scheme of the experimental stand of convective drying:

1 -drying chamber; 2 - heater; 3 - fan; 4 - potentiometer; 5 - instrument assembly;

6, 7 - automatic regulating system of temperature; 8 - electric resistance pyrometers;

9, 10, 11 - branch pipes with slide gates; 12 - psychrometer, 13 - express lattices

The automated program provides automatic collection and processing of information that characterizes the process, as well as conducts calculations for plotting the process kinetics. This made it possible to obtain and compare the kinetic and velocity characteristics of pumpkin seeds drying more accurately, promptly and reliably.

3. To determine the biochemical properties of pumpkin seeds, a drying was occurred to an equilibrium moisture content $(12 \%)$.

4. The dried seeds were divided into two parts:

4.1. The first part was used to determine the biochemical properties of the material.

4.2. The second part was used to determine the residual moisture content of the material (paragraph 1).

5. After determining the absolutely dry mass of the sample, the computer program determined the current moisture content of the material $W$ during drying, carried out calculations and constructed the curves of the drying process kinetics: $W=f(\tau), d W / d \tau=f(W)$. 


\section{Results and discussion}

Drying of seeds plays an important role in the process of preserving its native properties and is characterized by physical and mechanical properties of the material.

The physical and mechanical properties of pumpkin seeds variety, depending on the change in the moisture content of the material (from 0 to $46 \%$ ), obtained during the studies, are given in Table 1.

The physico-mechanical properties of pumpkin seeds

Table 1

\begin{tabular}{|c|c|c|c|}
\hline Characteristic & \multicolumn{3}{|c|}{ Value } \\
\hline Humidity, \% & $\mathbf{0}$ & $\mathbf{1 6}$ & $\mathbf{4 6}$ \\
\hline Length, $\mathrm{mm}$ & $17,4-20,0$ & $20,5-21,0$ & $20-21,5$ \\
\hline Width, $\mathrm{mm}$ & $10-11,0$ & $10,5-11,2$ & $11,7-12,2$ \\
\hline Height, $\mathrm{mm}$ & $2,1-2,2$ & $2,2-2,3$ & $2,6-2,9$ \\
\hline Mass of 1000 seeds, g & $168-172$ & $210-215$ & $310-316$ \\
\hline Density, $\mathrm{g} / \mathrm{cm}^{3}$ & $0,32-0,35$ & $0,36-0,40$ & $0,48-0,5$ \\
\hline Bulk weight, $\mathrm{kg} / \mathrm{m}^{3}$ & $265-277$ & $280-300$ & $378-390$ \\
\hline
\end{tabular}

So for the seeds there is an increase in the geometric dimensions of the seed: length by $38 \%$, width by $10 \%$ and thickness by $8 \%$ ( Figure 2 ).

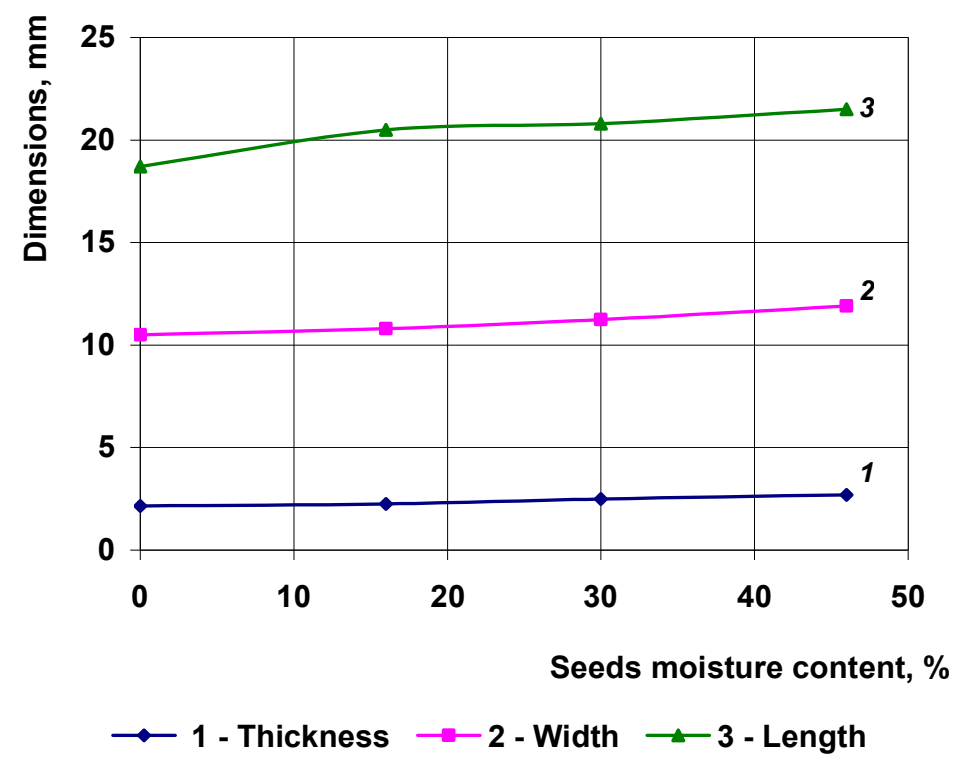

Figure 2. Change of the geometric dimensions of pumpkin seeds depending on the moisture content of the material 
Dehydration of plant materials, in particular pumpkin seeds, is one of the most important technological stages, which significantly affects the quality of finished products.

In this paper, the results of a study of pumpkin seeds drying on a test bench of convection drying in the elementary layer are presented.

Experimental studies of the drying process of pumpkin seeds were carried out in the temperature range of the drying agent from 40 to $80{ }^{\circ} \mathrm{C}$ and the speed of the drying agent was $1.5 \mathrm{~m} / \mathrm{s}$ (Figure 3).

The curves of drying kinetics, thermograms and drying rates are built in automatic mode, so there are no points of the process on the presented curves.

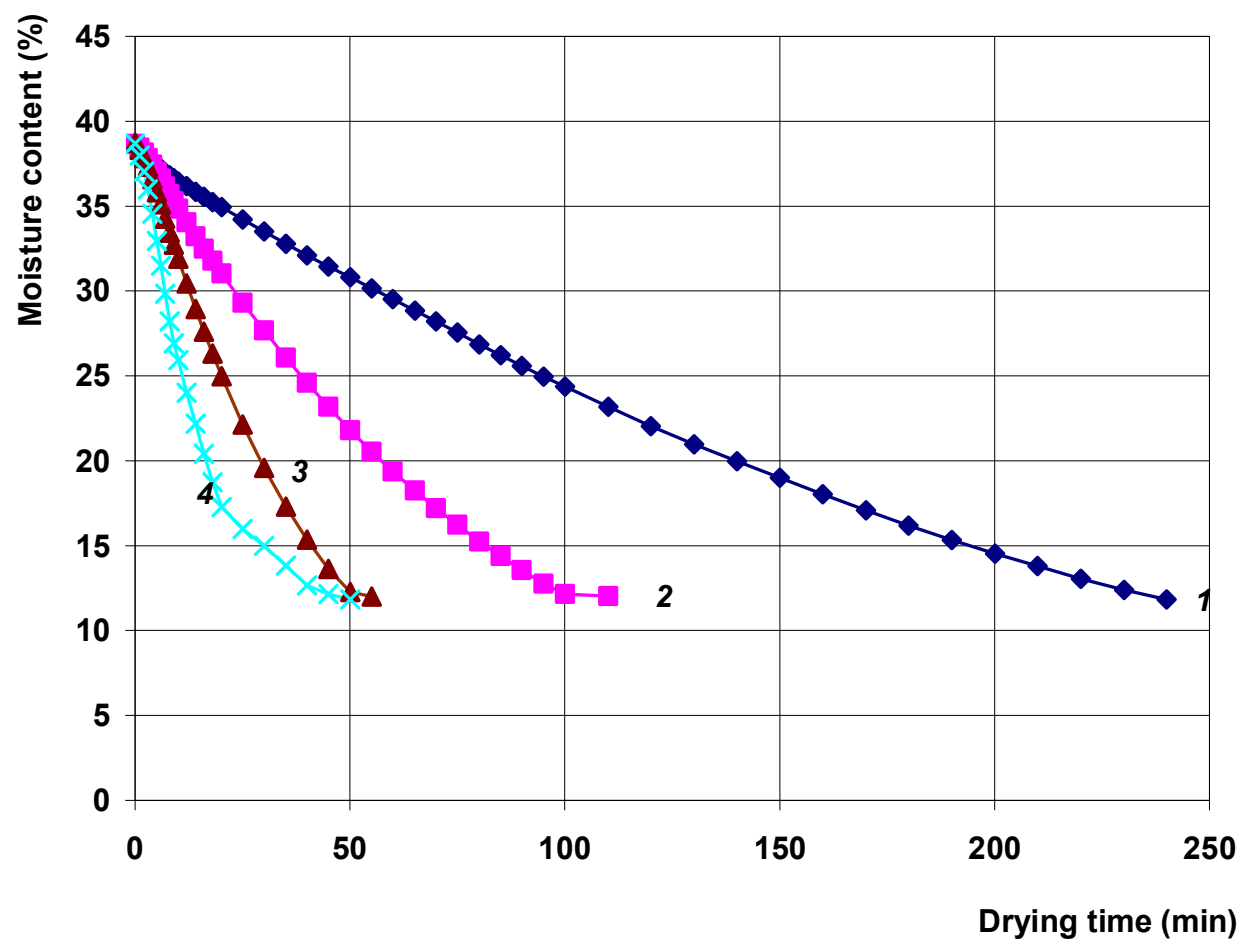

Figure 3. Curves of drying of pumpkin seeds

$(\mathrm{V}=1.5 \mathrm{~m} / \mathrm{s}, \mathrm{d}=10 \mathrm{~g} / \mathrm{kg} \mathrm{d.a.})$

at temperature values of the drying agent:

$1-40{ }^{\circ} \mathrm{C}, 2-50{ }^{\circ} \mathrm{C}, 3-60{ }^{\circ} \mathrm{C}, 4-80{ }^{\circ} \mathrm{C}$

The need to obtain high-quality seedling material (pumpkin seeds) requires a more thorough analysis of the research results. Thus, drying at $40{ }^{\circ} \mathrm{C}$ is a long process and takes 240 minutes, which is 2.4 times higher than the drying time at a temperature of $50{ }^{\circ} \mathrm{C}$. At $80^{\circ} \mathrm{C}$, the duration is only 32 minutes, which is almost 8 times faster than the drying time at $40{ }^{\circ} \mathrm{C}$.

The rates of drying curves indicate that the highest drying rate at a critical point at $80{ }^{\circ} \mathrm{C}$ is $1.6 \% / \mathrm{min}$, the lowest at $40{ }^{\circ} \mathrm{C}$ is $0.26 \% / \mathrm{min}$. (Figure 4 ).

Thus, with the increase in the drying agent temperature from 40 to $80{ }^{\circ} \mathrm{C}$, the drying rate increases by 6.15 times. The type of the curves of drying speed does not change and 
indicates that the drying process of the pumpkin seeds passes the periods of heating to the critical point and the falling drying rate. Drying occurs to an equilibrium moisture content of $12 \%$.

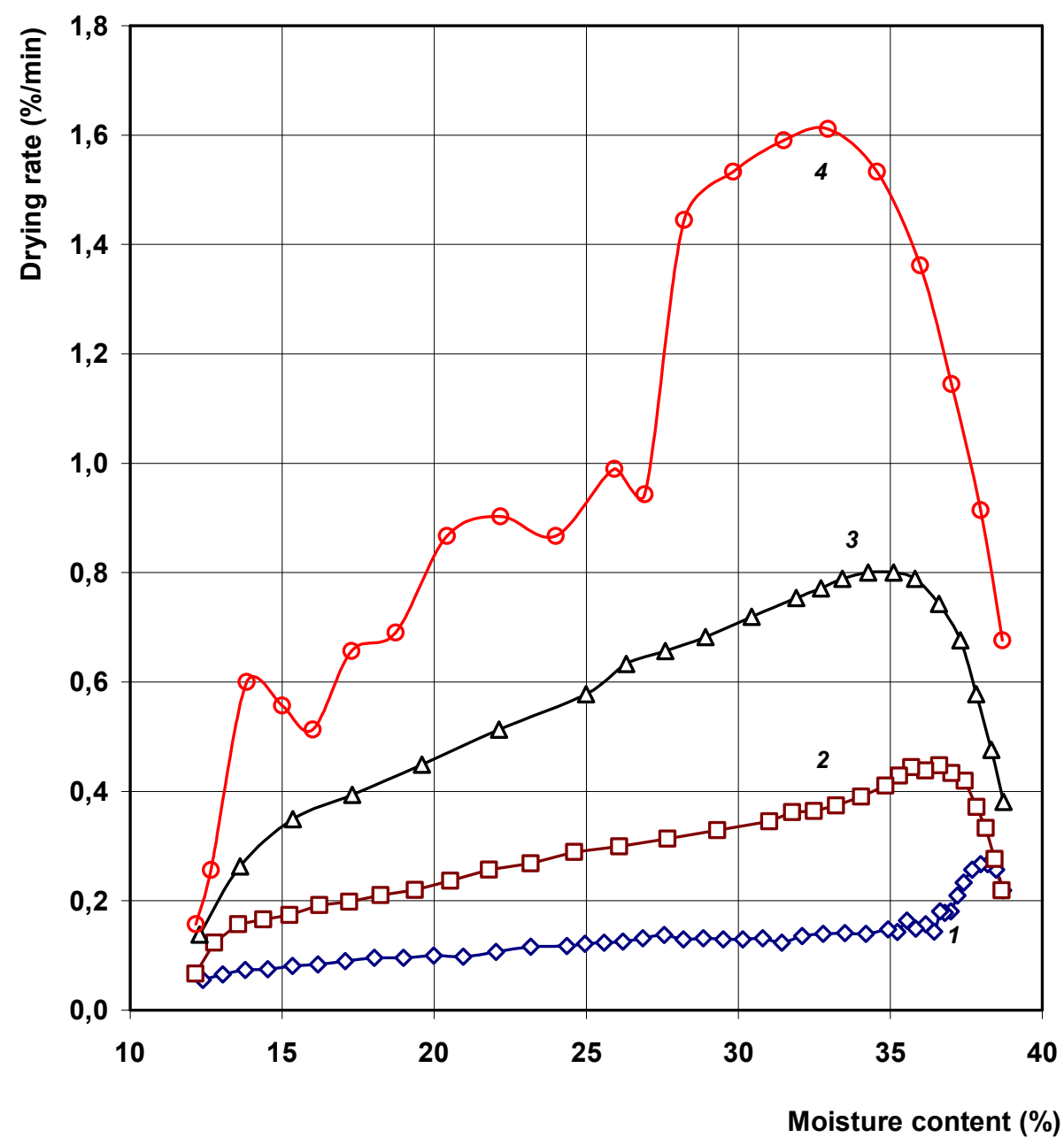

Figure 4. Drying rate curves of pumpkin seeds $(\mathrm{V}=1.5 \mathrm{~m} / \mathrm{s}, \mathrm{d}=10 \mathrm{~g} / \mathrm{kg} \mathrm{d.a.})$ at temperature values of the drying agent:

$$
1-40^{\circ} \mathrm{C}, 2-50^{\circ} \mathrm{C}, 3-60^{\circ} \mathrm{C}, 4-80^{\circ} \mathrm{C}
$$

The thermograms ( Figure 5) show the temperature change of pumpkin seeds during the heating at different drying agent temperatures. The seeds are warmed up from 3 to 5 minutes, then the temperature does not change significantly. 


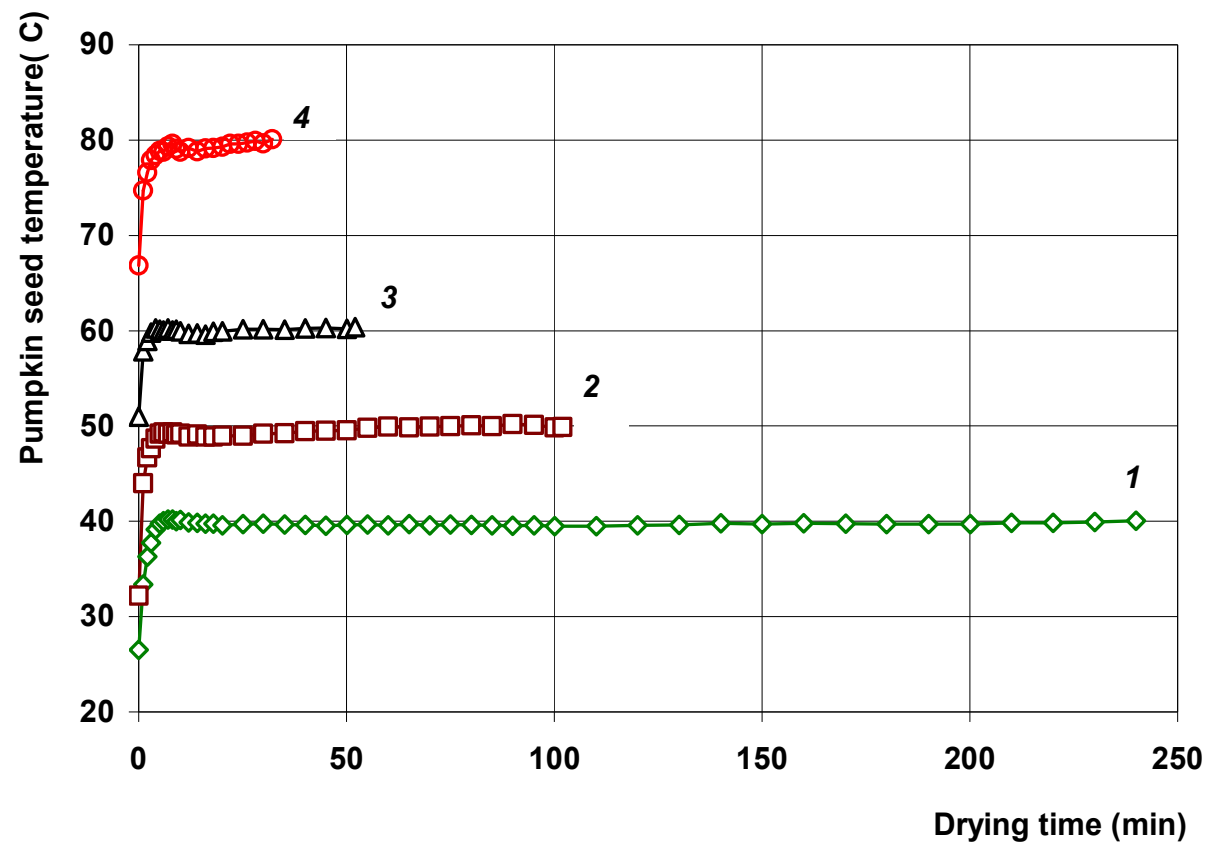

Figure 5. Thermograms of heating of pumpkin seeds depending on the drying temperature: $1-40^{\circ} \mathrm{C}, 2-50^{\circ} \mathrm{C}, 3-60^{\circ} \mathrm{C}, 4-80^{\circ} \mathrm{C}$

An increase in the temperature of the drying agent results in an increase in the final temperature of the material - the difference between the temperature of the drying agent and the final seeds temperature is $0.1-0.5^{\circ} \mathrm{C}$. So at a temperature of the drying agent $80{ }^{\circ} \mathrm{C}$ the final temperature is $79.5^{\circ} \mathrm{C}$, and at $40^{\circ} \mathrm{C}$ is $39.9^{\circ} \mathrm{C}$.

To determine the rational drying mode, it is necessary to determine the quality parameters of the pumpkin seeds, depending on the temperature of the drying agent (Table 2).

Table 2

Influence of drying modes on quality parameters of pumpkin seeds

\begin{tabular}{|c|c|c|c|c|c|c|}
\hline \multirow{3}{*}{ № } & \multicolumn{3}{|c|}{$\begin{array}{l}\text { Process parameters } \\
\end{array}$} & \multicolumn{3}{|c|}{ Quality parameters } \\
\hline & \multirow{2}{*}{$\begin{array}{c}\text { Drying agent } \\
\text { temperature } \\
\mathrm{t}^{\circ}{ }^{\circ} \mathrm{C}\end{array}$} & \multirow{2}{*}{$\begin{array}{c}\text { Speed of } \\
\text { movement } \\
\text { V, M/c }\end{array}$} & \multirow[t]{2}{*}{$\begin{array}{c}\text { Drying } \\
\text { time } \tau, \text { min }\end{array}$} & \multicolumn{2}{|c|}{$\begin{array}{l}\text { Germination } \\
\text { energy } E, \%\end{array}$} & \multirow{2}{*}{$\begin{array}{c}\text { Germinability } \\
\text { on the } 10^{\text {th }} \\
\text { day, C, } \%\end{array}$} \\
\hline & & & & $\begin{array}{l}5^{\text {th }} \\
\text { day }\end{array}$ & $\begin{array}{c}7^{\text {th }} \\
\text { day }\end{array}$ & \\
\hline 1. & \multicolumn{3}{|c|}{ Initial seeds } & 17 & 99 & 100 \\
\hline 2. & 40 & 1,5 & 240 & 15 & 90 & 98 \\
\hline 3. & 50 & 1,5 & 102 & 7 & 86 & 96 \\
\hline 4. & 60 & 1,5 & 52 & 7 & 69 & 90 \\
\hline 5. & 80 & 1,5 & 32 & - & - & 0 \\
\hline
\end{tabular}


The best results of the pumpkin seeds quality correspond to a drying temperature of 40 ${ }^{\circ} \mathrm{C}$ : the germination energy on 7 -th day is $90 \%$, and the germinability on 10 -th day is $98 \%$. The increase in temperature reduces the germinability on $4 \%$ relatively the initial seeds at a temperature of the drying agent of $50^{\circ} \mathrm{C}$, and, accordingly, on $10^{\circ} \mathrm{C}$ with an increase to 60 ${ }^{\circ} \mathrm{C}$. When the temperature of the drying agent increases to $80^{\circ} \mathrm{C}$, the final loss of the seeds germinability occurs.

Visually assess the effect of drying agent temperature on germinability at the initial moisture content of pumpkin seeds $38 \%$ it is possible by photos of germination on 5-th, 7th, 10-th days ( Figure 6-8). Thus, active germination occurs of seeds that have been dried at a temperature of $40{ }^{\circ} \mathrm{C}$ and almost is absent at a temperature of $80{ }^{\circ} \mathrm{C}$.

From the data of the influence of drying agent temperature on the germinability of pumpkin seeds it is established that the most appropriate mode of drying is: the drying agent temperature $40{ }^{\circ} \mathrm{C}$ and the speed of movement $1.5 \mathrm{~m} / \mathrm{s}$ (the effect of the initial humidity is not significant at that). In this mode, the germinability of pumpkin seeds is $98 \%$.

The mathematical processing of the experimental data obtained was carried out using the method of V.A. Danilov [11].

This method shows that there is a proportionality between the drying rate in the first period $\mathrm{N}$ at any mode and the inverse of the length of the process $\tau_{\mathrm{T}}$ from the initial moisture $\mathrm{Wp}$ to the final $\mathrm{Wk}$, and this proportionality is maintained at all modes of drying.

$$
\begin{gathered}
N \approx \frac{1}{\tau_{T}} \\
\frac{\tau}{\tau_{\mathrm{T} 1}}=\frac{\tau}{\tau_{T 2}}=\ldots=\left(\frac{\tau}{\tau_{T}}\right)=\text { const }
\end{gathered}
$$

This means that for a given current moisture content $\mathrm{W}$, if $\mathrm{Wp}$ and $\mathrm{Wk}$ are unchanged the value $\frac{\tau}{\tau_{\mathrm{T}}}$ remains constant regardless of the drying mode.

In Figure 9 the drying curve of pumpkin seeds is shown, which is transferred to the coordinate system $W-\left(\tau / \tau_{\mathrm{T}}\right)$ and is transformed into a single generalized drying curve.

Generalized curves of dry kinetics of pumpkin seeds, constructed by Danilov V.A. method for different regimes, are practically coincide. 


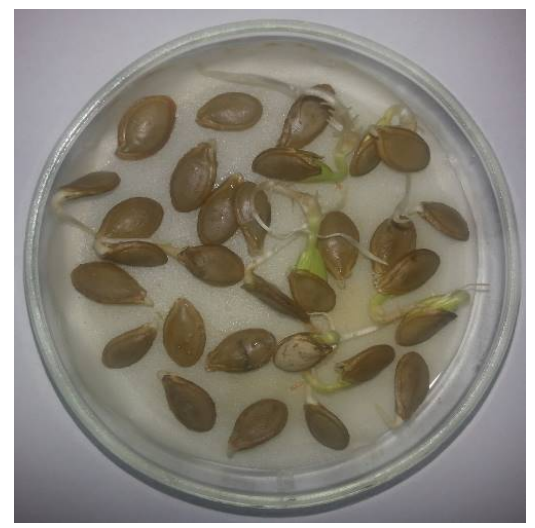

Initial seeds

$$
(\mathrm{C}=17 \%)
$$

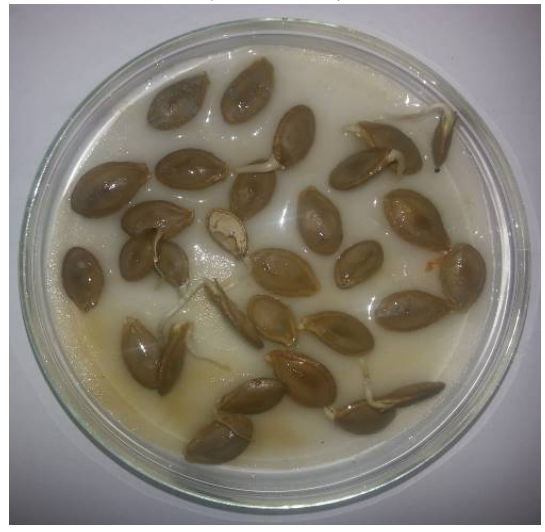

Drying agent temperature $50{ }^{\circ} \mathrm{C}$

$$
(\mathrm{C}=7 \%)
$$

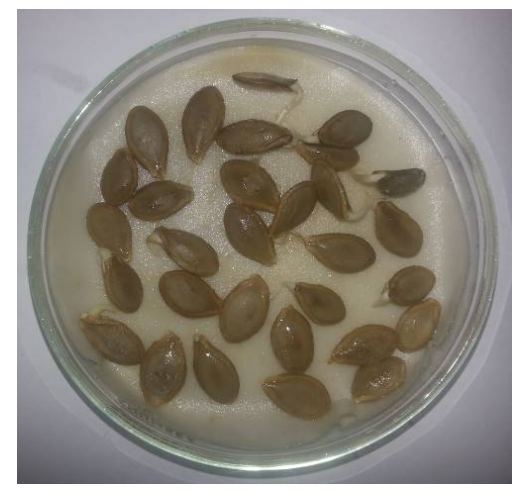

Drying agent temperature $40{ }^{\circ} \mathrm{C}$

$(\mathrm{C}=15 \%)$

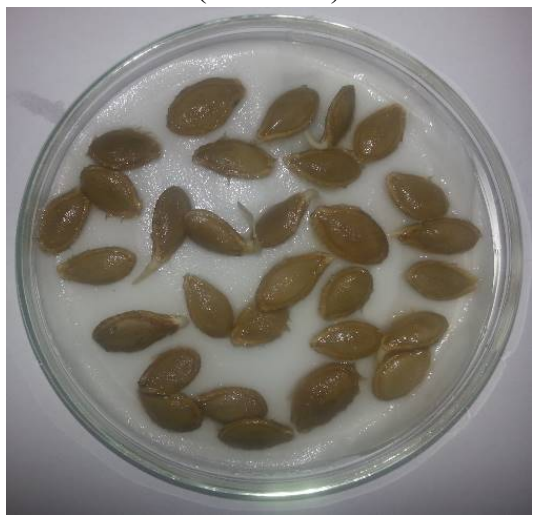

Drying agent temperature $60{ }^{\circ} \mathrm{C}$ $(\mathrm{C}=7 \%)$

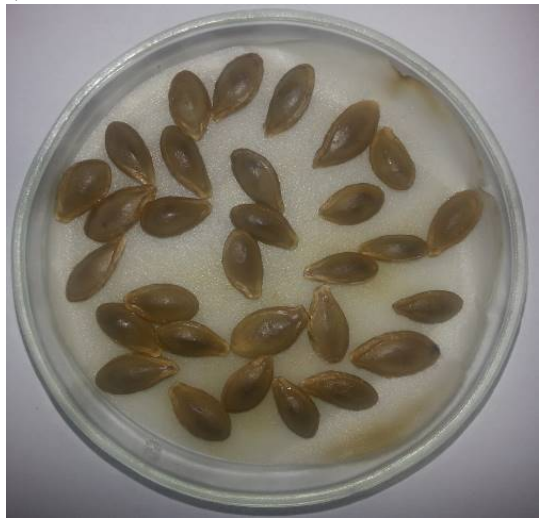

Drying agent temperature $80{ }^{\circ} \mathrm{C}$

$$
(\mathrm{C}=0 \%)
$$

Figure 6. Effect of drying agent temperature on the germ inability of pumpkin seeds on 5-th day of germination 


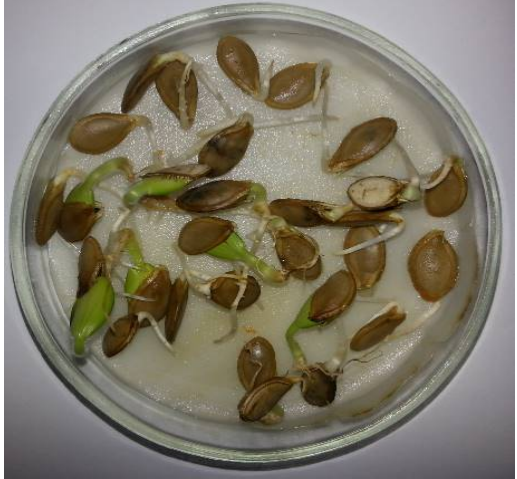

Initial seeds

$(\mathrm{C}=99 \%)$

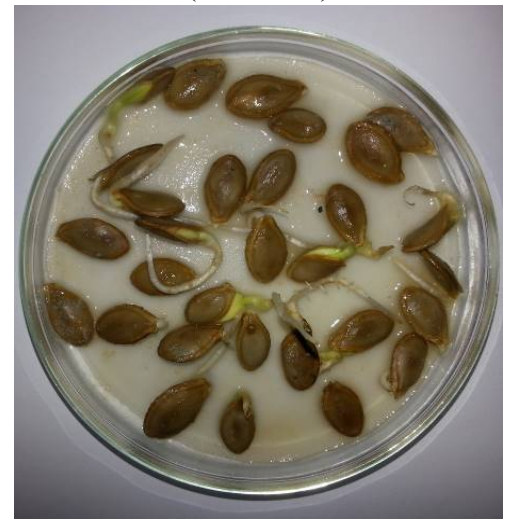

Drying agent temperature $50{ }^{\circ} \mathrm{C}$ $(\mathrm{C}=86 \%)$

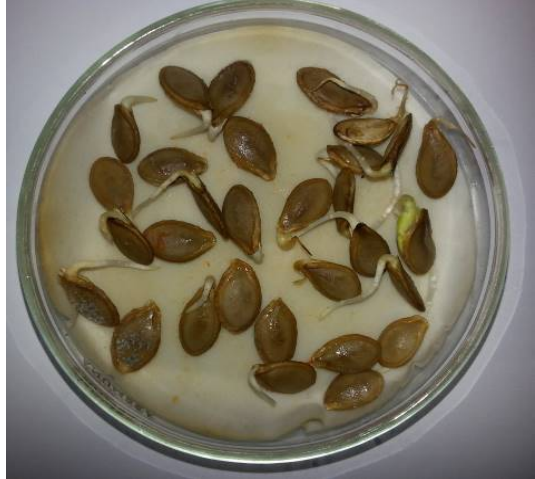

Drying agent temperature $40{ }^{\circ} \mathrm{C}$

$$
(\mathrm{C}=90 \%)
$$

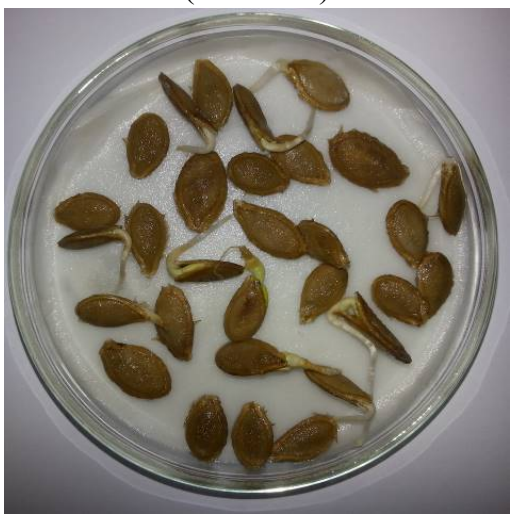

Drying agent temperature $60{ }^{\circ} \mathrm{C}$ $(\mathrm{C}=69 \%)$

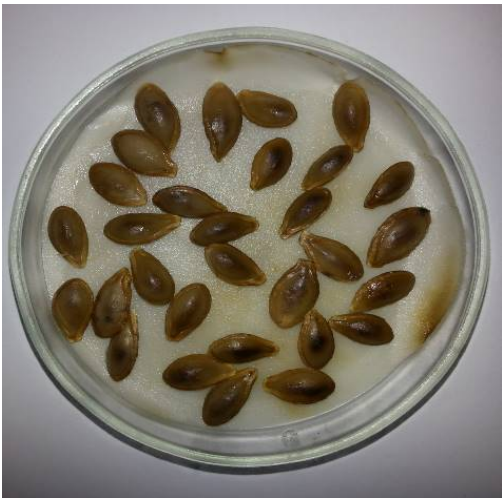

Drying agent temperature $80{ }^{\circ} \mathrm{C}$

$$
(\mathrm{C}=0 \%)
$$

Figure 7. Effect of drying agent temperature on the germinability of pumpkin seeds on the $7^{\text {th }}$ day of germination 


\section{— Processes and Equipment-}

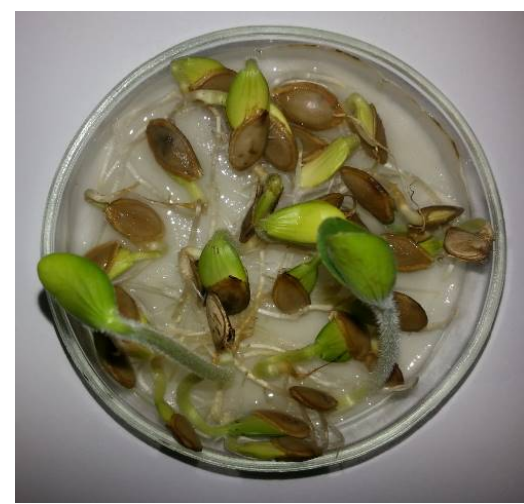

Initial seeds

$(\mathrm{C}=100 \%)$

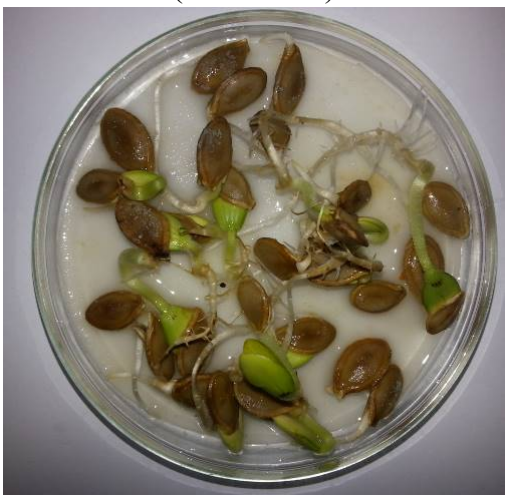

Drying agent temperature $50^{\circ} \mathrm{C}$

$$
(\mathrm{C}=96 \%)
$$

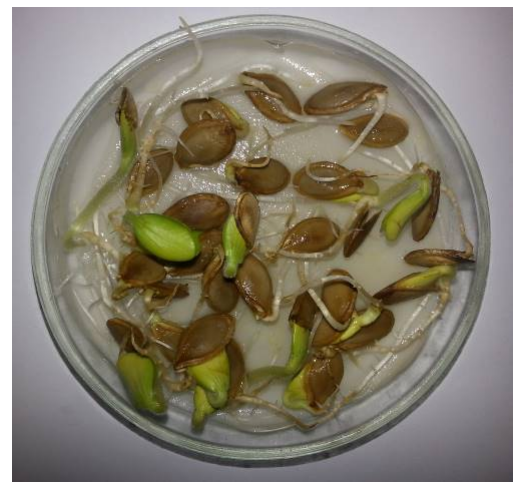

Drying agent temperature $40^{\circ} \mathrm{C}$ $(\mathrm{C}=98 \%)$

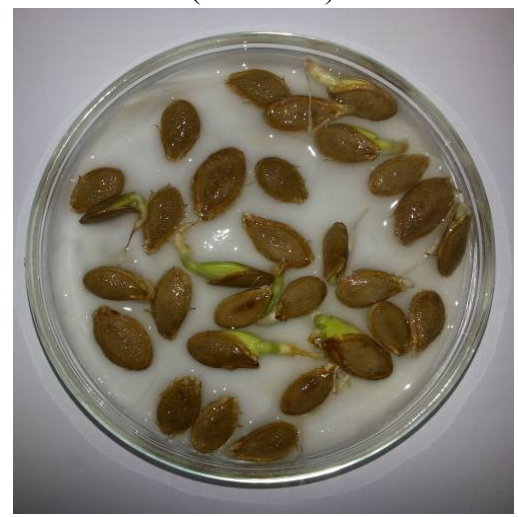

Drying agent temperature $60{ }^{\circ} \mathrm{C}$

$$
(\mathrm{C}=90 \%)
$$

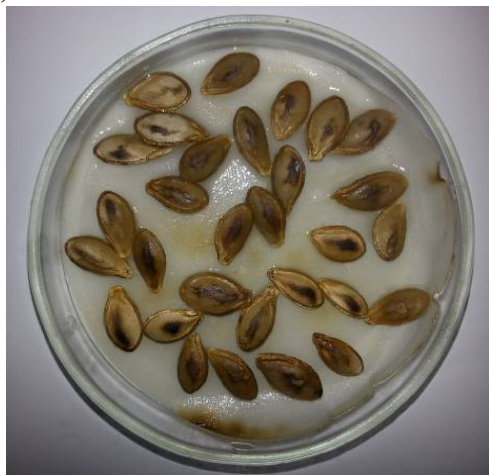

Drying agent temperature $80{ }^{\circ} \mathrm{C}$

$$
(\mathrm{C}=0 \%)
$$

Figure 8. Effect of drying agent temperature on the germinability of pumpkin seeds on the $10^{\text {th }}$ day of germination 


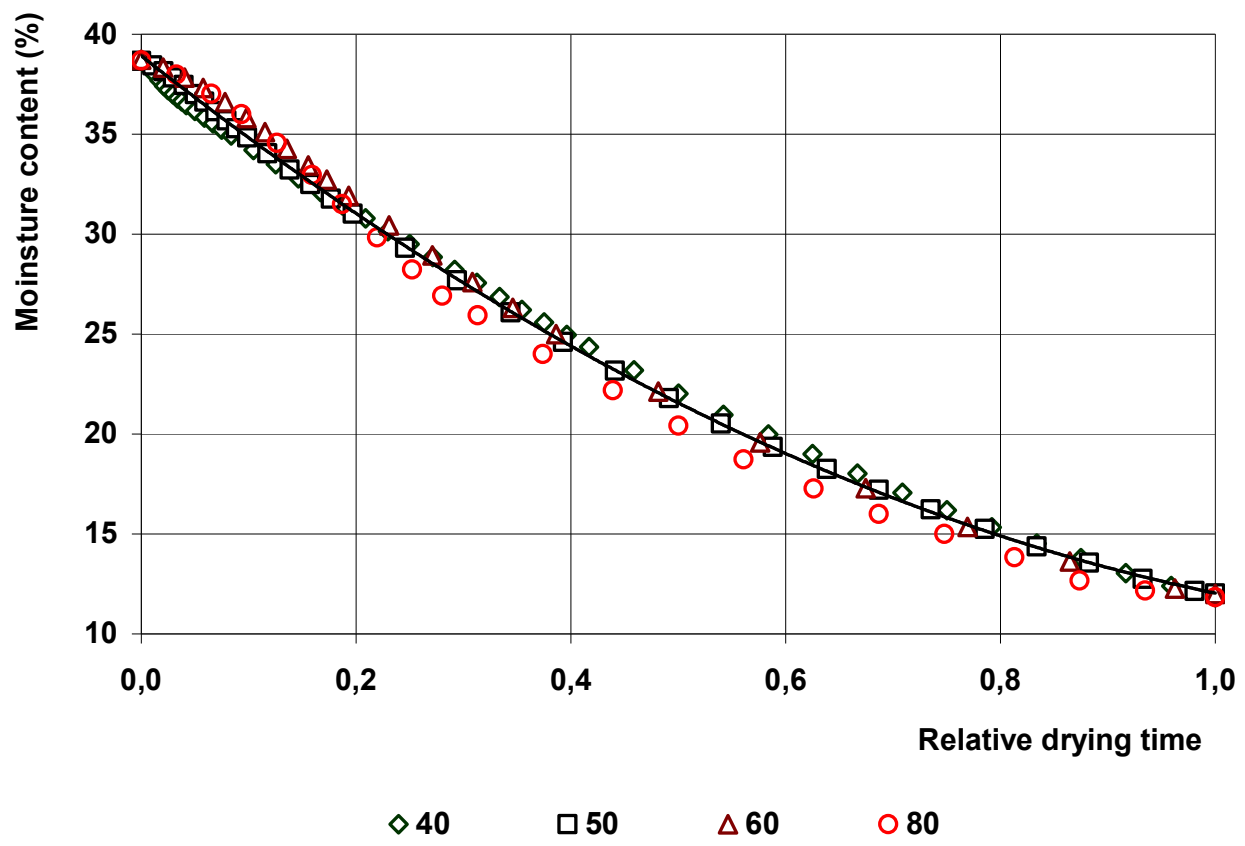

Figure 9. Generalized curve of kinetics of pumpkin seeds drying in the coordinates $W-\left(\tau / \tau_{\mathrm{T}}\right)$

The generalized drying curve can be constructed on the basis of one experimental drying curve of pumpkin seeds obtained at any drying mode, which greatly simplifies the study of drying kinetics.

The generalized curve of drying kinetics was differentiated graphically, and a generalized curve of drying rate of pumpkin seeds was received.

In Figure 10 a generalized drying rate curve with a maximum drying rate of $0.45 \% / \mathrm{min}$ is shown.

The drying process of pumpkin seeds takes place during the periods of heating and falling drying rates with the critical points $W \kappa_{1}, W_{\kappa} 2$ and $W \kappa 3$.

The generalized drying curves of pumpkin seeds constructed in semi-logarithmic coordinates indicate that the drying process, regardless of the drying regime, takes place during the period of the falling drying rate and is divided into three stages with corresponding critical points. So in [7] it is also noted that drying occurs during the period of the falling drying rate. The obtained results of the study showed that when the temperature increases, the drying intensity increases, and the duration decreases by 8 times with the increasing of the drying agent temperature from 40 to $80{ }^{\circ} \mathrm{C}$. While in [9] it is indicated that drying lasts for 8 hours at a temperature of $30{ }^{\circ} \mathrm{C}$ and only 2 hours when the temperature increases to $70{ }^{\circ} \mathrm{C}$. 


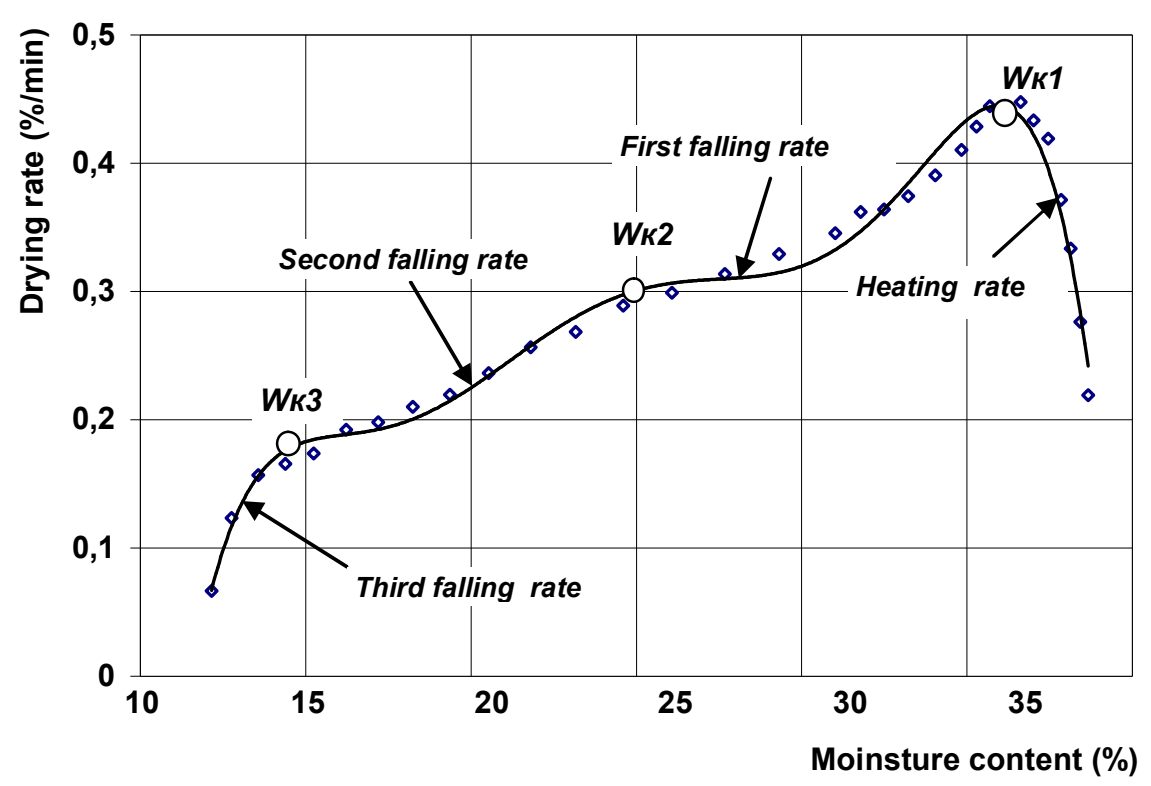

Figure 10. Generalized curve of drying rate of pumpkin seeds

\section{Conclusions}

It is recommended such a rational mode of pumpkin seeds drying variety: drying agent temperature $40{ }^{\circ} \mathrm{C}$, speed $-1,5 \mathrm{~m} / \mathrm{s}$. This is due to the biochemical properties of pumpkin seeds, in particular, the germinability, which, at the given drying mode, corresponds to the germinability of the control sample and is $98 \%$.

\section{References}

1. Joshi D.C., Mukherejee R.K. (1993), Physical properties of Pumpkin seeds, J. Agr. Eng.Res., 54, pp. 219-229.

2. Davies R.M. (2010), Engineering Properties of Three Varieties of Melon Seeds as Potentials for Development of Melon Processing Machines, Advance Journal of Food Science and Technology, 2(1), pp. 63-66.

3. Koocheki, A., Razavi S.M.A., Milani E., Moghadan T.M., Abedini M., Alamatiyan and S., Izadikhah S. (2007), Physical properties of watermelonseed as a function of moisture content and variety, Int. Agrophy., 21, pp. 349-359.

4. Manuwa S.I., Afuye G.G. (2004), Moisture dependentphysical properties of soyabean (Var-TGx 1871-5E), Nigeria J. Indust. Stud., 3(2), pp. 45-54.

5. Bart-Plange A. and Baryeh E.A. (2003), The Physicalproperties of category B cocoa beans, J. Food Eng., 60, pp. 219-227. 
6. Tabatabaeefa A., (2003), Moisture-dependent physicalproperties of wheat, Int. Agrophy., 12, pp. 207-211.

7. Sacilik K. (2007), Effect Of Drying Methods On Thin-Layer Drying Characteristics Of Hull-Less Seed Pumpkin (Cucurbita Pepo L.), Journal of Food Engineering, 79, pp. 23-30.

8. Akyol E., Susantez C., Kahveci K., Hacihafizoglu O., Kaya Y. (2015), Drying Simulation of Pumpkin Seed, Proceedings of the World Congress on Mechanical, Chemical, and Material Engineering (MCM 2015) Barcelona, Spain - July 20-21, Paper No. 320.

9. Guiné R. P. F., Pinho S., Barroca M. J. (2011), Study of The Convective Drying Of Pumpkin (Cucurbita Maxima), Food and Bioproducts Processing, 89, pp. 422-428.

10. Hashim N., Daniel O., Rahaman E. (2014), A Preliminary Study: Kinetic Model Of Drying Process Of Pumpkins (Cucurbita Moschata) İn A Convective Hot Air Dryer, Agriculture and Agricultural Science Procedia, 2, pp. 345-352.

11. Hukil W.V. (1954), Storage ol cereal grains and their products, Amer Assoc. Cer. Chem.

12. Kofoed S.S. (1964), Investigations on drying grain with slightly pre-heated air in thick layers, Copenhagen.

13. McEwen E.R. (1954), Through drying of deep beds of wheat grain, Engineer, 10, pp. 817-819.

14. Petrova Z., Snezhkin Y., Pazyuk V., Samoilenko K. (2015), Drying of Antioxidant Composite Materials based on Table Beet, Energy engineering and control systems, 1, pp. 25-28.

15. Vyacheslav Mykhailyk, Sviatoslav Lementar, Roman Yakobchuk, Yevhen Skrynnyk, Roman Semenko (2016), Wheat grain drying kinetics in a thin layer, Ukrainian Journal of Food Science, 4(2), pp. 316-326. 